\title{
The composition and properties of ash in the context of the modernisation of oil shale industry
}

\author{
Mai Uibu ${ }^{(\mathrm{a})}$, Kadriann Tamm $^{(\mathrm{a})}$, Regiina Viires ${ }^{(\mathrm{a})}$, Janek Reinik ${ }^{(\mathrm{b})}$, \\ Peeter Somelar(c), Lembi Raado ${ }^{(\mathrm{d})}$, Tiina Hain ${ }^{(\mathrm{d})}$, Rein Kuusik ${ }^{(\mathrm{a})}$, \\ Andres Trikkel ${ }^{(\mathrm{a})}$
}

(a) Laboratory of Inorganic Materials, Department of Materials and Environmental Technology, Tallinn University of Technology, Ehitajate tee 5, 19086 Tallinn, Estonia

(b) National Institute of Chemical Physics and Biophysics, Akadeemia tee 23, 12618 Tallinn, Estonia

(c) Department of Geology, University of Tartu, Ravila 14A, 50411 Tartu, Estonia

(d) Building Lifecycle Research Group, Department of Civil Engineering and Architecture, Tallinn University of Technology, Ehitajate tee 5, 19086 Tallinn, Estonia

Received 14.11.2019, accepted 16.05.2021, available online 10.06.2021

\begin{abstract}
The modernisation of the oil shale (OS) industry in Estonia over the last decade has also led to significant changes in the composition and binding properties of the ash generated as a by-product. These changes also influence the environmental impact that the ash can have. In the current investigation, oil shale ash (OSA) samples were collected from different points along the ash separation systems of a large pulverized fuel combustion plant (LCP), various points in a circulating fluidized bed (CFB) combustion plant, and from an oil shale pyrolysis plant that utilises oil shale to produce liquid fuels. The results obtained can be used for optimising the deposition conditions, as well as guiding utilisation-recycling processes for ash generated from changing oil shale composition and characteristics. When it comes to developing the circular economy aspects of oil shale utilisation, mapping out the properties of OSA is crucial.
\end{abstract}

Keywords: oil shale ash, circular economy, binding properties, leaching.

\section{Introduction}

Harmonised European environmental regulations are in a state of constant development. Air emissions, energy efficiency levels, resource efficiency, use

\footnotetext{
* Corresponding author: e-mail mai.uibu@taltech.ee

(C) 2021 Authors. This is an Open Access article distributed under the terms and conditions of the Creative Commons Attribution-NonCommercial 4.0 International License (http://creativecommons.org/licenses/by-nc/4.0/).
} 
of fuel (involving the share of renewables), and circular economy are just a few factors that influence the operation in environment-sensitive areas. The targets and measures of the European Union (EU) to reach higher environmental quality levels also affect the oil shale (OS) sector, one of the vital branches of Estonian economy. From the period of Estonia's pre-accession to the EU right up until today its oil shale industry has gone through a remarkable evolution. As a result, also the industry's environmental impact has significantly decreased.

From the technological point of view there are two main developmental directions for the use of oil shale:

- improvement of the pulverised firing (PF) process by adding additional pollutant removal systems (DeSOx) and/or swapping PF for fluidised bed combustion (FBC);

- transition from the direct burning of oil shale for electricity production to the pyrolysis with solid heat carrier for the co-production of liquid fuels, gas and electricity.

Today the trend in thermal power plants is to apply the FBC technology for co-combustion of OS and biomass. If solid fuel particles are fed into the fluidised bed whose temperature is the same as the fuel ignition temperature, then continuous combustion takes place with no need for higher temperatures. A typical bed temperature is between $750{ }^{\circ} \mathrm{C}$ and $950{ }^{\circ} \mathrm{C}$. When oil shale is burned in a CFB boiler, sulphur is completely captured by the Ca contained in ash and, therefore, the $\mathrm{SO}_{2}$ concentrations in the flue gases are very low. There is also no need to add limestone or other sorbents into the oil shale-fuelled $\mathrm{CFB}$ boiler as the $\mathrm{Ca} / \mathrm{S}$ molar ratio in OS is high. The CFB technology has been employed in Estonian oil shale industry since 2004 [1].

When it comes to converting the energy in oil shale to a more easily usable form, one option is the co-production of liquid fuels, gas and electricity by means of OS pyrolysis process and the use of excess heat and by-products. Pyrolysis is the thermal decomposition of oil shale accompanied by heat transfer. In Enefit140 (EN140) and Enefit280 (EN280) processes oil shale is heated in the absence of air to a temperature of $450-550{ }^{\circ} \mathrm{C}$. As a result, it undergoes pyrolysis, producing shale oil (with different fractions of liquid fuel), oil shale gas (non-condensable organic compounds) and solid residual material. The latter still contains some organics that will be burned off in the afterburning process. In this process cycle, hot OSA is acting as a heat carrier and, therefore, the process is called the solid heat carrier pyrolysis. Both Enefit140 and Enefit 280 technologies can use oil shale with a wide range of particle sizes. During the pyrolysis, most of the carbon is converted into new products, which results in lower direct $\mathrm{CO}_{2}$ emissions when compared to those from the direct burning of OS. Low air emissions coming from the combined use of CFB combustion with Enefit280 technology represent another environmental gain. In the latter, the excess heat will be converted into electricity to maximise the overall energetic efficiency of the process.

By now, new technologies for OS processing have been applied [2-6] 
and research towards developing OS oxy-fuel combustion technology has started [7-10]. These technologies yield solid wastes whose properties differ completely from those of wastes generated by obsolete methods [11-17]. By today, possibilities of using OS ash have been quite extensively studied and some have been realised (mainly based on outdated pulverised firing technology). The related areas are: production of cement and building blocks [18-20], preparation of curing mixtures and manufacturing of construction aggregates [21, 22], road base construction and strengthening/stabilizing of peat ground arrays [23], backfilling of underground mines [24], quick neutralization of acidic soils and production of granulated soil conditioners with modified composition $[25,26]$. Oil shale is also utilised as a polymer filler, a raw material for precipitated calcium carbonate production [27-29], a component of ceramic plates and geopolymers [30], and materials with zeolitic properties, tobermorites [31-33], a phosphorus sorbent in municipal sewage treatment $[34,35]$, and an acidic gases sorbent $\left(\mathrm{CO}_{2}\right.$ and $\left.\mathrm{SO}_{2}\right)[36,37]$.

The utilisation of OSA in several potentially voluminous areas, such as ground stabilization, mine backfilling, recultivation of abandoned mining sites, production of building materials, is related to its curing properties. The latter depend on the content of free $\mathrm{CaO}$ and secondary silicates in OSA.

At the same time, a trend today is to use lower firing temperatures in combustion processes, which results in a higher content of undecomposed carbonates and a lower content of clinker minerals in ash. Lower firing temperatures also cause a significant deterioration of the curing properties of ash. In addition, modifications to the ash separation systems alter its fractional composition and may affect utilisation as well.

The main aim of the current research is to study the properties of ash, a solid waste from Estonian oil shale combustion and retorting, focusing on its reusability and environmental impact. The results obtained will provide the basis for elucidating the most effective, profitable and environmentally friendly technology for OSA reuse.

\section{Materials and methods}

\subsection{Ash samples}

Ash samples taken from the industrial processing units of the Enefit Energiatootmine Oil Plant in Auvere were provided by AS Eesti Energia.

The DeSOx ash was collected from the pulverised firing unit at Eesti Power Plant (PP). The boiler temperature in pulverised firing could range to $1450{ }^{\circ} \mathrm{C}$. The fly ash was moved from the boiler to the novel integrated desulphurisation (NID) technology-based reactor where $\mathrm{SO}_{2}$ was aggregated with the ash, which was separated from the flue gases by using bag filters. As a result, the $\mathrm{SO}_{2}$ concentrations in the flue gases were reduced from as high as $3400 \mathrm{mg} / \mathrm{Nm}^{3}$ to about $400 \mathrm{mg} / \mathrm{Nm}^{3}$. 
The CFB ash was collected from Auvere PP, the world's newest oil shale plant. The electrostatic precipitator ash (ESPA) samples from fields 1-5 (Auvere ESPA, collected on 31.07.2015) were mixed proportionally to formation: $65 \%$ from field 1, 30\% from field 2, 2.5\% from field 2, $2 \%$ from field 4 and $0.5 \%$ from field 5 . The total OS processing residue (Auvere total) was used as received from the main silo.

The cyclone ash (CA) from fields 1-5 (EN140 CA, mixed according to formation shares as follows: $73.7 \%$ from field 1, 17.9\% from field 2 and $8.4 \%$ from field 3 ), the finer fraction of CA from fields $2-3$ (EN140 CA2-3, mixed as follows: $68 \%$ from field 2 and $32 \%$ from field 3 ) and the electrostatic precipitator ash (EN140 ESPA) were collected from Enefit140 units between 07.05.2015 and 22.07.2015.

The bottom ash (EN280 BA), cyclone ash (EN280 CA) and total processing residue from the ash silo (EN280 total) were collected from Enefit280 units between 10.03.2015 and 12.06.2015.

\subsection{Chemical and phase composition}

The total carbon (TC) and total inorganic carbon (TIC) values were determined using an Eltra CS 580 Carbon Sulphur Determinator. The contents of free lime ( $\mathrm{fCaO}$ ) and sulphur forms (total sulphide, sulphates, and pyrites) were determined applying ethylene glycol [38] and EVS 664:1995 [39] methods, respectively. The chemical and phase composition was determined by X-ray fluorescence (XRF) spectroscopy (Rigaku Primus II at Tallinn University of Technology's Department of Geology) and quantitative X-ray diffraction (XRD) (Bruker 8D Advanced).

\subsection{Leaching tests}

The standard batch leaching test, UNI EN 12457-2 [40], was applied to samples at the materials' own pH levels (pHmat). The ash sample (grain size $95 \%<1 \mathrm{~mm}$ ) was divided into two sub-samples (75 g each), which were shaken in two separate sealed glass bottles (1 L each) with $750 \mathrm{~mL}$ of ultrapure deionised water (Milli-Q, Advantage A10 System, Millipore SAS) for 24 hours at laboratory room temperature $\left(20 \pm 2{ }^{\circ} \mathrm{C}\right)$. The suspension $(\sim 600 \mathrm{~mL})$ was separated by means of a vacuum filtration system which was equipped with a water aspirator pump, a $1 \mathrm{~L}$ filter flask, a Büchner funnel and a disposable $0.45 \mu \mathrm{m}$ PA membrane filter (HIMIFIL). The funnel was cleaned with $15.8 \mathrm{~mol} / \mathrm{L}$ $\mathrm{HNO}_{3}$ and rinsed several times with ultrapure water before use. About $100 \mathrm{~mL}$ of the filtrate was used for $\mathrm{pH}$ and electric conductivity measurements and the rest was decanted into a $0.5 \mathrm{~L}$ PET bottle for the measurement of total dissolved solids (TDS) and dissolved organic carbon (DOC), as well as for the analysis of ions and trace elements. The bottle with water extracted from the replicate sample was not opened before the analysis of phenols was carried 
out. Water extracted from bottle 2 was delivered to the laboratory immediately after the leaching test.

The electric conductivity and $\mathrm{pH}$ of the filtrated extract were determined immediately after the leaching test by means of a BENCH PC $510 \mathrm{pH} /$ Conductivity Meter (Eutech Instruments Pte Ltd, Singapore/Oakland Instruments). The analyses of filtrates for TDS, DOC, trace elements, cations and anions were conducted in the laboratory of Gesellschaft für Bioanalytik $\mathrm{mbH}$ in Pinneberg (Germany) in accordance with the respective standards [41-45]. Phenols were analysed chromatographically in the central laboratory of the Health Board (Estonia). All analyses were conducted using accredited standard methods. One blank test for the presence of trace elements was carried out applying the same procedure but with no sample. The contents of the selected trace elements in water extracted from the blank test were found to be below the limit for quantification (LOQ) and no leaching method-related contamination could be detected.

\subsection{Binding properties}

The Brauner-Emmet-Teller (BET) method with a Kelvin 1042 sorptometer (Costech Microanalytical SC) was used to estimate the BET specific surface area (SSA) of ash. The SSA was also measured by the Blaine method in accordance with EVS-EN 196-6:2018 [46]. The particle size distribution was estimated using a Horiba LA-950 laser-scattering particle size distribution analyser. In addition, the gradation test was carried out in accordance with EVS-EN 933-1:2012 [47]. The particle surface and structure were analysed using a Zeiss EVO 15 Scanning Electron Microscope (SEM). The loss on ignition (LOI), determined in a muffle furnace for a period of three hours at temperatures of $105{ }^{\circ} \mathrm{C}, 520^{\circ} \mathrm{C}$ and $975{ }^{\circ} \mathrm{C}$, and the indissoluble residue in aqua regia were also found out.

The pozzolanic activity of ash (the rate of the reaction between a pozzolan and $\mathrm{Ca}(\mathrm{OH})_{2}$ in the presence of water) was determined in the saturated $\mathrm{Ca}(\mathrm{OH})_{2}$, solution over a period of 30 days in accordance with EVS-EN 196-5 [48].

The binding properties of all ash samples were tested in two stages: firstly with hardened ash pastes and then with mortars. The water demand, setting times and soundness of ash pastes were determined according to EVS-EN 196-3 [49]. The main purpose of the soundness test was to determine the risk of expansion by means of the hydration of unbound calcium and magnesium oxides. While determining the setting times, the test pieces were stored not in water, but in $>95 \% \mathrm{RH}$. This was necessary due to the slow hardening rate of the ash. Expansion of Le Chatelier was determined after hardening in a humid environment over a period of seven days. Pastes were made with standard consistency and were hardened in Le Chatelier moulds for seven days at $20 \pm 2{ }^{\circ} \mathrm{C}$ and $>95 \%$ relative humidity $(\mathrm{RH})$. 
Strength development (bending strength and compressive strength) was tested by means of EVS-EN 196-1 [50] using the $40 \times 40 \times 160 \mathrm{~mm}$ prisms of a 1:3 ash/sand mortar that had been hardened for seven, 14 and 28 days. The water to ash ratio was between $0.5-0.8$. The moulded and compacted sample bodies first hardened for 48 hours in moulds, then over five days at $60 \% \mathrm{RH}$ and $20 \pm 2{ }^{\circ} \mathrm{C}$, and further hardening continued for 28 days at $>95 \% \mathrm{RH}$ and $20 \pm 2{ }^{\circ} \mathrm{C}$.

\section{Results and discussion}

\subsection{Chemical and phase composition}

The ash studied was relatively similar in macro compound content (Fig. 1) to that investigated earlier by Bityukova et al. [13] and Kuusik et al. [51]. The compound composition and respective ratios of the latter were as follows: $\mathrm{CaO}(28-38 \%), \mathrm{SiO}_{2}(21-31 \%), \mathrm{Al}_{2} \mathrm{O}_{3}(5-8 \%), \mathrm{Fe}_{2} \mathrm{O}_{3}(3-4 \%)$ and $\mathrm{MgO}$ (3-5\%). For comparison the results about OSA samples obtained previously by Raado et al. [15] and Uibu et al. [24] are also given. The samples had been collected from different points along the ash separation systems of PF (CA and PF ESPA1, respectively, from the block 1A cyclone and the electrostatic precipitator field 1) and CFB (CFB ESPA1, from the block 8A and the electrostatic precipitator field 1) boilers at Eesti Power Plant. The ash investigated in the current research differed in chemical and phase composition as well as physical characteristics from that analysed by researchers previously $[13,15,16,24,51,52]$.

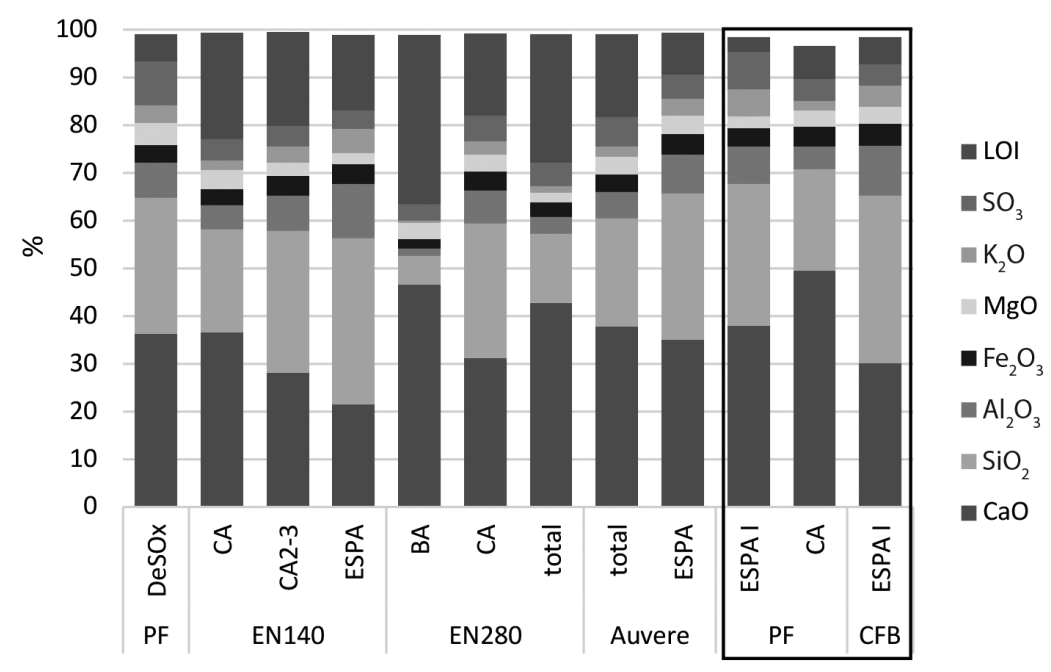

Fig. 1. The chemical composition of ash in comparison with that of PF ESPA1, PF CA and CFB ESPA1 determined in previous studies [15, 24]. 
Based on the XRD analysis results (Fig. 2), the samples were divided into two main groups. Group 1 included EN140, EN280 and Auvere total ashes whose main Ca carriers were carbonates (calcite and dolomite) with $18.7-71.1 \%$ and the content of free lime was below 1.2\%. Group 2 consisted of DeSOx ash and Auvere ESPA whose Ca was mainly present in lime and portlandite with 8.7-15.4\%, while the content of carbonates was low, $8.8-14.1 \%$. The C2S beta content together with other Ca-Mg silicates (merwinite and wollastonite) in group 2 was somewhat higher, $8.3-16.5 \%$, when compared to the $3.6-9.3 \%$ in group 1. Other XRD-detected silicates were quartz with 2.4-11.3\%, K-feldspar with $2.9-16.6 \%$ and mica with $1.1-13.3 \%$. The amorphous phase content estimates varied predominantly within $21-40 \%$, while substantially lower amorphous phase contents were found in EN280 BA and Auvere total ash, $8-12 \%$.

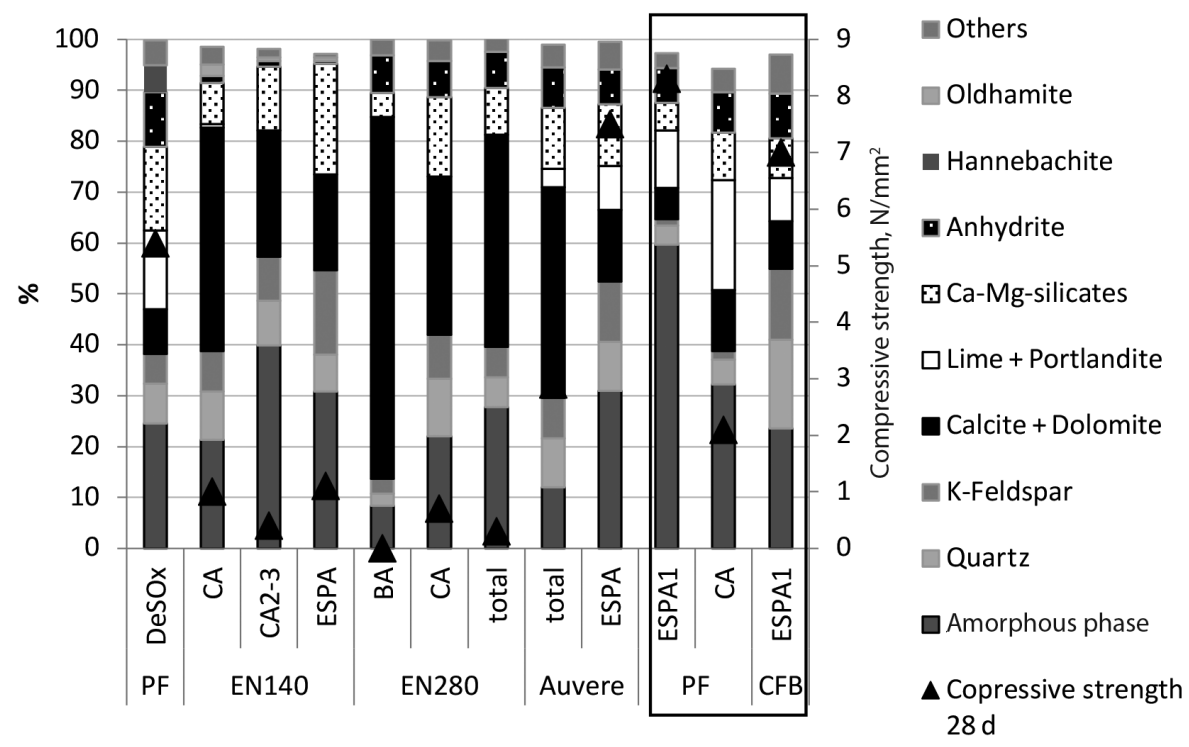

Fig. 2. The phase composition of DeSOx, EN140, EN280 and Auvere PP ashes and the resulting 28-day compressive strength of ash mortars in comparison with those of PF ESPA1, PF CA and CFB ESPA1 determined in previous studies [15, 24].

As expected, the DeSOx ash showed the highest sulphur content levels among all the OSA samples studied $\left(\mathrm{S}_{\text {total }}=3.7 \%\right)$ (Fig. 1), revealed by anhydrite $\left(\mathrm{CaSO}_{4}\right)$ and hannebachite $\left(\mathrm{CaSO}_{3} \cdot 0.5 \mathrm{H}_{2} \mathrm{O}\right)$ (Fig. 2). Anhydrite with $7-8 \%$ was found to be the dominant sulphur phase in EN280 and Auvere $\mathrm{PP}$ ashes. Sulphides were mainly present in the form of oldhamite $(\mathrm{CaS})$ in the EN140 ash $\left(\mathrm{S}_{\text {sulfides }}=0.4-0.7 \%\right)$ (Fig. 3). Auvere ESPA and DeSOx ash appeared to be most similar in chemical and phase composition to the ashes 
studied previously $[15,24]$. The TIC content was the highest in EN280, EN140 CA and Auvere total ashes (Fig. 3). In DeSOx, EN280 and Auvere ashes it remained relatively low, but was noticeably higher in the EN140 ash (Fig. 3). The chloride and fluoride contents in the ashes studied were $<0.051 \%$ and $<0.13 \%$, respectively (Table 1 ).

The ashes' high contents of microelements $\mathrm{Cr}$ (11-118 ppm), $\mathrm{Pb}$ (26-203 ppm), As (11-61 ppm), Ba (9-371 ppm) and Mo (3-7 ppm) (Table 1) are of concern from an environmental aspect.

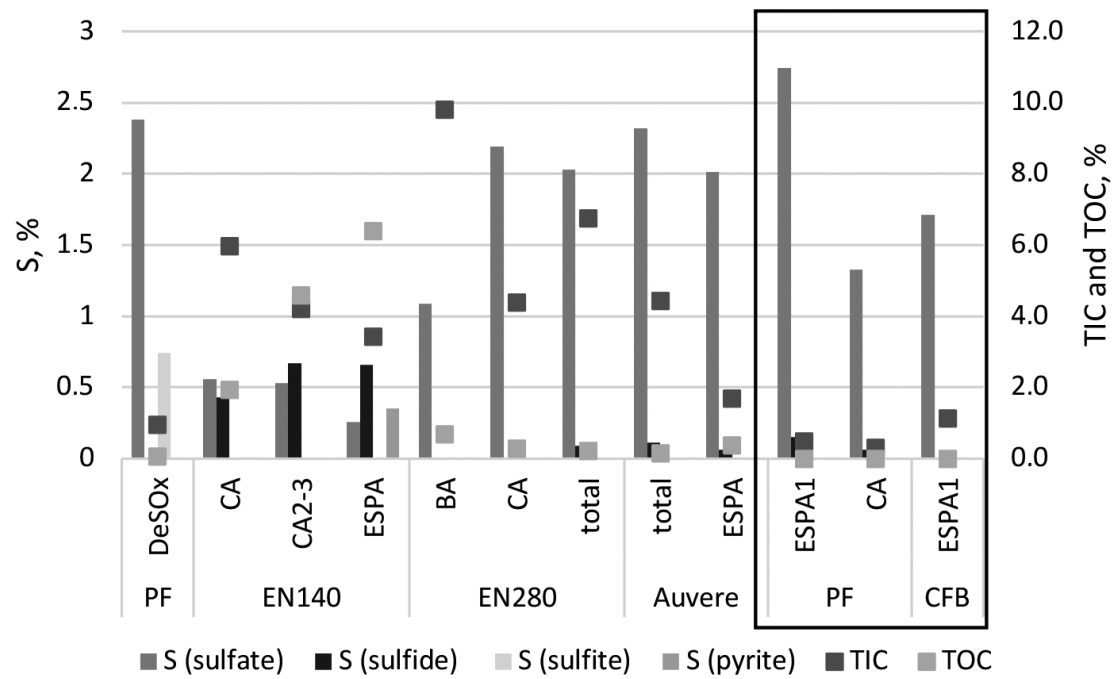

Fig. 3. The distribution of sulphur and carbon forms in ash in comparison with that in PF ESPA1, PF CA and CFB ESPA1 established in previous studies $[15,24]$. 
Table 1. The content of microelements

\begin{tabular}{|c|c|c|c|c|c|c|c|c|c|}
\hline Ash & DeSOx & $\begin{array}{l}\text { EN140 } \\
\text { CA }\end{array}$ & $\begin{array}{l}\text { EN140 } \\
\text { CA2-3 }\end{array}$ & $\begin{array}{l}\text { EN140 } \\
\text { ESPA }\end{array}$ & $\begin{array}{l}\text { EN280 } \\
\text { BA }\end{array}$ & $\begin{array}{l}\text { EN280 } \\
\text { CA }\end{array}$ & $\begin{array}{l}\text { EN280 } \\
\text { total }\end{array}$ & $\begin{array}{l}\text { Auvere } \\
\text { total }\end{array}$ & $\begin{array}{l}\text { Auvere } \\
\text { ESPA }\end{array}$ \\
\hline As, ppm & 32.6 & 14.6 & 37.3 & 61.1 & 11.7 & 34.9 & 18.5 & 25.5 & 32.3 \\
\hline $\mathrm{Ba}, \mathrm{ppm}$ & 190.5 & 153.1 & 291.9 & 371.8 & $<50$ & 210.3 & 138.6 & 169.7 & 245.8 \\
\hline $\mathrm{Br}, \mathrm{ppm}$ & 371.7 & 165.9 & 225.4 & 430.5 & 52.6 & 266.6 & 182.7 & 214.8 & 382.4 \\
\hline $\mathrm{Ce}, \mathrm{ppm}$ & $<50$ & $<50$ & $<50$ & $<50$ & $<50$ & $<50$ & $<50$ & $<50$ & $<50$ \\
\hline $\mathrm{Co}, \mathrm{ppm}$ & $<20$ & $<20$ & $<20$ & $<20$ & $<20$ & $<20$ & $<20$ & $<20$ & $<20$ \\
\hline $\mathrm{Cr}, \mathrm{ppm}$ & 60.4 & 67.9 & 117.8 & 78.5 & 11.7 & 44.1 & 42.3 & 44.6 & 63.2 \\
\hline $\mathrm{Cu}, \mathrm{ppm}$ & 17.1 & 16 & 21.6 & 17.2 & 12 & 12.9 & 14.6 & 16.4 & 21.4 \\
\hline $\mathrm{F}, \%$ & $<0.1$ & $<0.1$ & $<0.1$ & $<0.1$ & $<0.1$ & 0.13 & $<0.1$ & $<0.1$ & $<0.1$ \\
\hline $\mathrm{Cl}, \%$ & 0.018 & 0.048 & 0 & 0 & 0.023 & 0.006 & 0.03 & 0.051 & 0.018 \\
\hline $\mathrm{Ga}, \mathrm{ppm}$ & 5.7 & $<5$ & 9.6 & 13.4 & $<5$ & 7.4 & $<5$ & 5.6 & 6 \\
\hline $\mathrm{Ge}, \mathrm{ppm}$ & $<5$ & $<5$ & $<5$ & $<5$ & $<5$ & $<5$ & $<5$ & $<5$ & $<5$ \\
\hline $\mathrm{La}, \mathrm{ppm}$ & $<50$ & $<50$ & $<50$ & $<50$ & $<50$ & $<50$ & $<50$ & $<50$ & $<50$ \\
\hline Mo, ppm & $<5$ & $<5$ & 6.7 & 7 & $<5$ & 5.9 & $<5$ & 5.1 & 6.6 \\
\hline $\mathrm{Nb}, \mathrm{ppm}$ & 6.7 & $<5$ & 6 & 9.9 & 2.7 & 7.3 & $<5$ & 5.2 & 5.6 \\
\hline $\mathrm{Nd}, \mathrm{ppm}$ & $<50$ & $<50$ & $<50$ & $<50$ & $<50$ & $<50$ & $<50$ & $<50$ & $<50$ \\
\hline $\mathrm{Ni}, \mathrm{ppm}$ & 26 & 30.8 & 42 & 44.5 & 13.6 & 27.4 & 21.6 & 25.4 & 34.4 \\
\hline $\mathrm{Pb}, \mathrm{ppm}$ & 122.6 & 36.4 & 55.4 & 203.4 & 26.7 & 59 & 24.6 & 49 & 71.6 \\
\hline $\mathrm{Rb}, \mathrm{ppm}$ & 108 & 50.9 & 85.2 & 133.9 & 11.1 & 69.6 & 45.4 & 56.2 & 87.8 \\
\hline Se, ppm & $<5$ & $<5$ & $<5$ & $<5$ & $<5$ & $<5$ & $<5$ & $<5$ & $<5$ \\
\hline Sr, ppm & 230.2 & 251.9 & 289 & 297 & 266.8 & 270 & 308.9 & 284.2 & 324.7 \\
\hline Th, ppm & $<10$ & $<10$ & $<10$ & $<10$ & $<10$ & $<10$ & $<10$ & $<10$ & $<10$ \\
\hline $\mathrm{U}, \mathrm{ppm}$ & $<10$ & $<10$ & $<10$ & $<10$ & $<10$ & $<10$ & $<10$ & $<10$ & $<10$ \\
\hline $\mathrm{V}, \mathrm{ppm}$ & 43.9 & 34 & 56.8 & 91.6 & $<20$ & 47.2 & 34.8 & 34.5 & 59.2 \\
\hline $\mathrm{Y}, \mathrm{ppm}$ & 8.3 & 10.1 & 10.5 & 14.2 & 6.3 & 10.4 & 10.7 & 11.2 & 13.3 \\
\hline $\mathrm{Zn}, \mathrm{ppm}$ & 191.2 & 74.1 & 59.1 & 54.4 & 107.2 & 89.3 & 58.1 & 145 & 109.7 \\
\hline $\mathrm{Zr}, \mathrm{ppm}$ & 91.4 & 70.7 & 102.4 & 118.7 & 21.9 & 86 & 53.5 & 73.6 & 98.4 \\
\hline
\end{tabular}




\subsection{Leaching characteristics}

As previous studies have shown, oil shale ash undergoes an alkaline reaction when it comes into contact with water [16, 24, 53-55]. The water extracts of DeSOx and Auvere PP ashes exhibited the highest values of electric conductivity and $\mathrm{pH}$. Much lower $\mathrm{pH}(11.5-11.9)$ and electrical conductivity values of EN28O ash leachates indicated that ashes from modernised combustion technologies are of lower basicity. At the same time, the alkaline effect of OSA as a waste needs to be paid attention to. However, although characterised by certain hazardous, mainly alkaline properties, OS ashes should be classified as non-hazardous wastes, similarly to coal ashes [56]. The registration of burnt oil shale as a chemical under the REACH regulation and in the database of the European Chemicals Agency means that it can be used as a raw material and its alkalinity becomes an advantage [57].

The released quantities of priority contaminants $\mathrm{Hg}, \mathrm{Cd}, \mathrm{Pb}$ and $\mathrm{Ni}$ [58] from all ash samples at given conditions were below the detection limit, except for EN140 ESPA. Of the hazardous elements $\mathrm{As}, \mathrm{Ba}, \mathrm{Cr}$ and $\mathrm{Cu}$, as classified in [59], the release of chromium from EN280 and DeSOx ash samples was clearly observable. The release of Mo from most of the samples was notable and was almost similar to that reported previously $[54,60]$.

The release of total dissolved solids and chlorides from all ash samples was considerable, except for EN280 BA. The lowest release of sulphates was observed for the EN140 ash and Auvere ESPA. The release of fluorides was substantial in case of all samples, except for the EN280 ash.

The quantity of dissolved organic carbon released varied between 56 and $275 \mathrm{mg} / \mathrm{kg}$ (Table 2). There was observed a minor release of phenols, mainly from the EN140 ESPA sample. Similar findings have been reported in a previous study on the leaching of retorting ash [54].

\subsection{Binding properties}

The utilisation of oil shale ash as a mineral binder depends upon the course of hydration which determines the development of strength and durability of hardened stone in water. The PF ash, which comes from electrostatic precipitators and has historically been a constituent of Portland cement [61], is characterised by predominantly hydraulic properties with slightly pozzolanic effects. Additionally, this ash reduces the demand for water in cement paste, thereby increasing the strength and durability of hardened concretes [62]. The hydration of CFB ESPA is mostly pozzolanic in nature and is characterised by increased water demand. Previously the hardening of CFB and PF electrostatic precipitator ashes were shown to reach the same compressive strength during the first 28 days, but the subsequent hydraulic hardening of CFB ash was hindered due to the lack of calcium silicates and aluminates [15]. 


\begin{tabular}{|c|c|}
\hline 4 & $\begin{array}{l}0 \\
\dot{0} \\
\dot{0} \\
v\end{array}$ \\
\hline 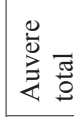 & 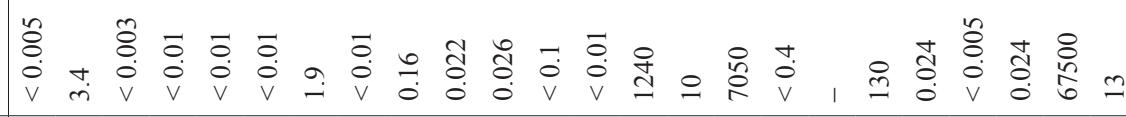 \\
\hline 郎 & 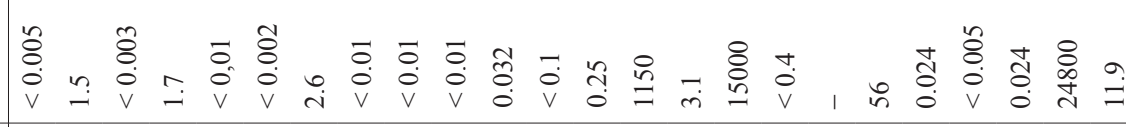 \\
\hline 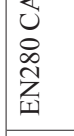 & 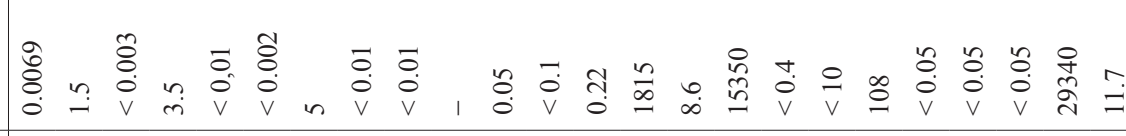 \\
\hline 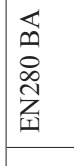 & 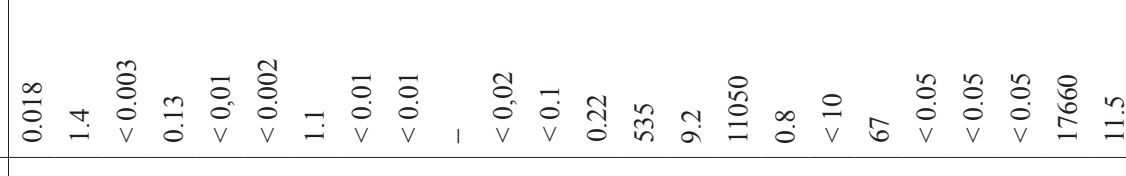 \\
\hline 至皿 & 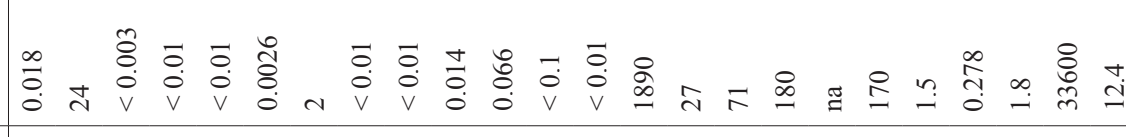 \\
\hline 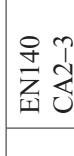 & 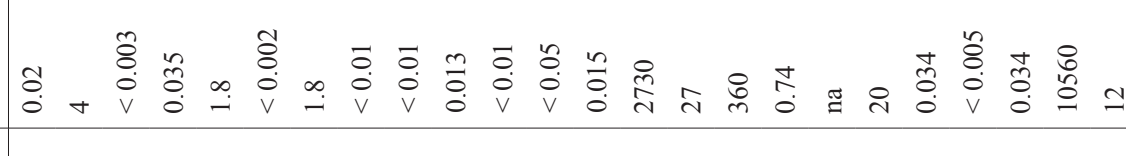 \\
\hline$\overline{\mathrm{i}}$ & 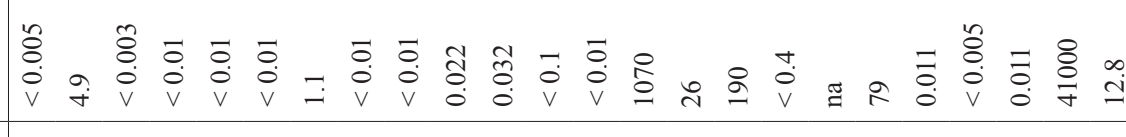 \\
\hline 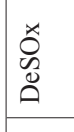 & 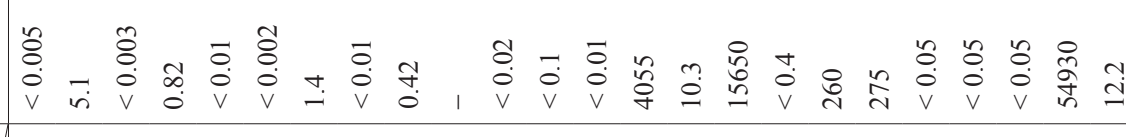 \\
\hline$\frac{5}{4}$ & 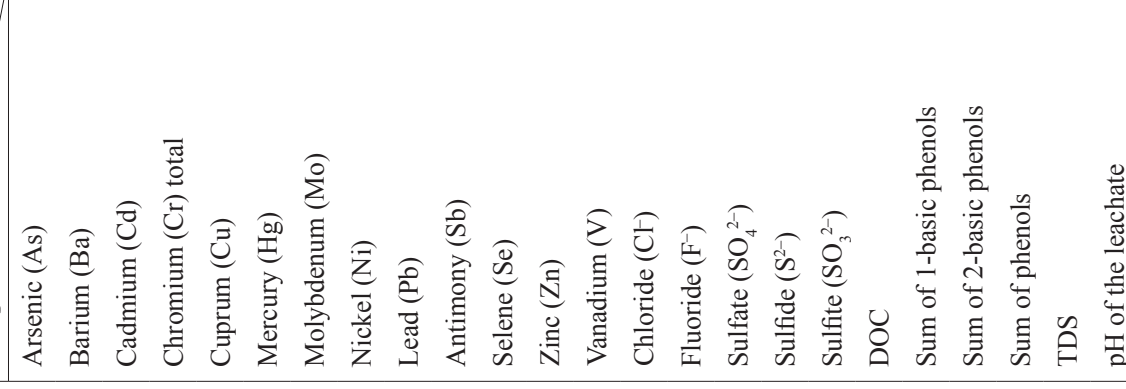 \\
\hline
\end{tabular}




\subsubsection{Physical characteristics}

The PF ash has been characterised by a low specific surface area, and the CFB ash by a high specific surface area, which is caused by a higher porosity of the latter [51]. Of the novel ash types, the DeSOx ash exhibited the lowest BET SSA, $1.25 \mathrm{~m}^{2} / \mathrm{g}$, and an average grain size of $12.75 \mu \mathrm{m}$ (Table 3). The low BET SSA value was also indicative of the formation of the melted phase which affected the DeSOx ash particle surface, as shown in Figure 4a. Enefit 280 BA contained more than $60 \%$ coarse fractions ( $>1 \mathrm{~mm}$; Table 4$)$, while its BET SSA was $1.52 \mathrm{~m}^{2} / \mathrm{g}$. The Enefit 280 and Auvere total ashes also contained coarser particles, which complicates their usage as binders (Table 4). The average particle size of EN280 and EN140 cyclone ashes was in the range of 34-39 $\mu \mathrm{m}$, while their BET SSA remained between 5.0 and $5.5 \mathrm{~m}^{2} / \mathrm{g}$ (Table 3). The average particle size of EN140 CA2-3 and Auvere ESPA varied between 12 and $16 \mu \mathrm{m}$ and the BET SSA ranged from 5.8 to $6.0 \mathrm{~m}^{2} / \mathrm{g}$. As expected, EN140 ESPA had the finest particle size, $\mathrm{d}_{\text {mean }}=5 \mu \mathrm{m}$, BET SSA $=11.7 \mathrm{~m}^{2} / \mathrm{g}$ (Table 3). EN140, EN280 and Auvere ESPA were characterised by irregular particle shape and porous surface (Fig. 4, b-c).
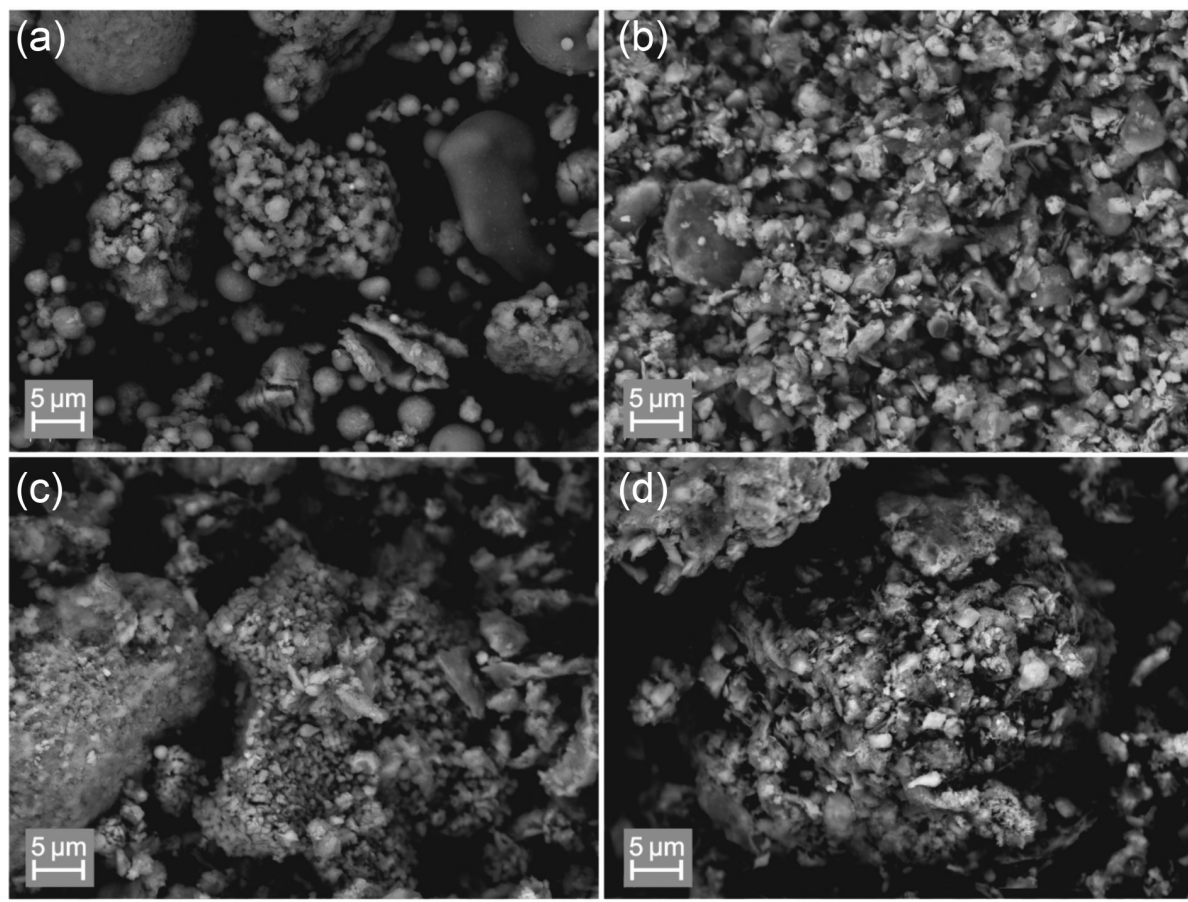

Fig. 4. SEM microphotographs of (a) DeSOx ash, (b) EN140 ESPA, (c) Auvere ESPA, (d) EN280 CA. 


\subsubsection{Loss on ignition}

The LOI at $105{ }^{\circ} \mathrm{C}$ indicated that all ash samples contained some moisture $(<0.35 \%)$. As expected, the content of organics was the highest in the finest fractions of EN140 ash (LOI $=6.38 \%$ for EN140 ESPA at $105-520{ }^{\circ} \mathrm{C}$; Table 3), which was also confirmed by TOC values, as shown in Figure 3 . The content of undecomposed carbonates was the highest in the coarser fractions of EN280 and EN140 ashes (LOI at $520-975{ }^{\circ} \mathrm{C}$; Table 3), and the lowest in the DeSOx ash, as is also shown by TIC analysis (Fig. 3).

Table 3. The density, specific surface area, mean particle size, loss on ignition and indissoluble residue of ashes

\begin{tabular}{|c|c|c|c|c|c|c|c|c|}
\hline \multirow{2}{*}{ Ash Parameter } & \multirow{2}{*}{$\begin{array}{c}\text { Density, } \\
\mathrm{g} / \mathrm{cm}^{3}\end{array}$} & \multirow{2}{*}{$\begin{array}{c}\mathrm{d}_{\text {mean }}, \\
\mu \mathrm{m}\end{array}$} & \multirow{2}{*}{$\begin{array}{l}\text { Blaine } \\
\mathrm{SSA}, \\
\mathrm{m}^{2} / \mathrm{kg}\end{array}$} & \multirow{2}{*}{$\begin{array}{l}\mathrm{BET} \\
\mathrm{SSA} \\
\mathrm{m}^{2} / \mathrm{g}\end{array}$} & \multicolumn{3}{|c|}{ Loss on ignition, $\%$} & \multirow{2}{*}{$\begin{array}{c}\text { Indissoluble } \\
\text { residue, } \\
\%\end{array}$} \\
\hline & & & & & $105^{\circ} \mathrm{C}$ & $105-520^{\circ} \mathrm{C}$ & $520-975^{\circ} \mathrm{C}$ & \\
\hline DeSOx & 2.64 & 12.75 & 342 & 1.25 & 0.20 & 0.82 & 4.97 & 15.52 \\
\hline EN140 CA & 2.68 & 38.83 & 261 & 4.98 & 0.14 & 0.28 & 22.06 & 20.54 \\
\hline EN140 CA2-3 & 2.63 & 13.96 & 344 & 6.06 & 0.19 & 2.89 & 15.61 & 35.70 \\
\hline EN140 ESPA & 2.51 & 5.07 & 1135 & 10.98 & 0.35 & 6.38 & 9.80 & 38.85 \\
\hline EN280 BA & 2.74 & - & pieces & 1.52 & 0.01 & 0.20 & 37.35 & 5.97 \\
\hline EN280 CA & 2.74 & 33.72 & 557 & 5.49 & 0.03 & 0.25 & 17.03 & 29.13 \\
\hline EN280 total & 2.74 & - & pieces & 3.47 & 0.07 & 0.20 & 26.11 & 15.88 \\
\hline Auvere total & 2.78 & 70.46 & 317 & 7.95 & 0.06 & 0.01 & 17.54 & 20.83 \\
\hline Auvere ESPA & 2.80 & 16.84 & 457 & 11.66 & 0.03 & 0.20 & 8.21 & 26.19 \\
\hline
\end{tabular}

Table 4. Sieving results for ashes

\begin{tabular}{|c|c|c|c|c|c|c|c|c|c|c|c|c|}
\hline Sieve size, & 10 & 8 & 4 & 2 & 1 & 0.5 & 0.25 & 0.125 & 0.09 & 0.063 & 0.032 & Pan \\
\hline & \multicolumn{12}{|c|}{$\%$ retained } \\
\hline DeSOx & \multirow{9}{*}{0.0} & \multirow{9}{*}{1.3} & \multirow{9}{*}{14.7} & \multirow{9}{*}{$\begin{array}{l}10.3 \\
24.9\end{array}$} & \multirow{9}{*}{$\begin{array}{l}13.3 \\
20.2\end{array}$} & \multirow{9}{*}{$\begin{array}{l}8.9 \\
13.5\end{array}$} & \multirow{9}{*}{$\begin{array}{c}7.2 \\
12.3\end{array}$} & \multirow{9}{*}{$\begin{array}{l}7.6 \\
9.0\end{array}$} & 1.2 & 2.9 & 6.1 & 89.8 \\
\hline EN140 CA & & & & & & & & & 17.4 & 9.4 & 17.5 & 55.7 \\
\hline EN140 CA2-3 & & & & & & & & & 1.0 & 2.0 & 10.2 & 86.8 \\
\hline EN140 ESPA & & & & & & & & & & 0.5 & 1.2 & 98.3 \\
\hline EN280 CA & & & & & & & & & 2.6 & 4.5 & 13.1 & 79.8 \\
\hline EN280 total & & & & & & & & & 2.9 & 3.1 & 7.1 & 39.6 \\
\hline EN280 BA & & & & & & & & & 1.8 & 1.0 & 0.7 & 0.6 \\
\hline Auvere total & & & & & & & & & 18.3 & 3.6 & 14.4 & 63.7 \\
\hline Auvere ESPA & & & & & & & & & 0. & 0.2 & 3.1 & 96.5 \\
\hline
\end{tabular}




\subsubsection{Pozzolanic properties}

Pozzolanic activity is a measure of the degree of reaction over time between a pozzolan and $\mathrm{Ca}^{2+}$ or $\mathrm{Ca}(\mathrm{OH})_{2}$ in the presence of water. The pozzolanic reaction converts a silica-rich precursor with no cementing properties into a calcium silicate with good cementing properties:

$$
\mathrm{CH}+\mathrm{SH} \rightarrow \mathrm{C}-\mathrm{S}-\mathrm{H}
$$

The pozzolanic activity towards, or the content of reactive $\mathrm{SiO}_{2}$ in free lime, is determined in the saturated $\mathrm{Ca}(\mathrm{OH})_{2}$ solution over the course of a 30-day period. Amongst the ashes studied, EN140 CA2-3 and EN140 ESPA exhibited pozzolanic properties (Fig. 5), which was also confirmed by their content of insoluble residue, 36-39\% (Table 3).
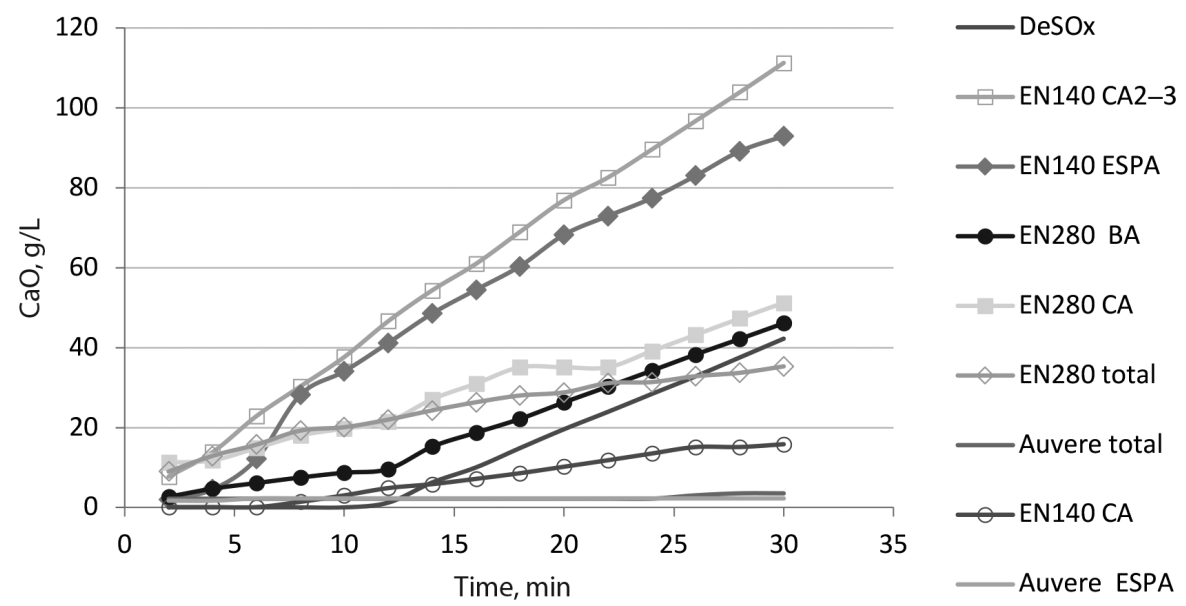

Fig. 5. The pozzolanic properties of ashes.

\subsubsection{The standard consistency, setting times and expansion of Le Chatelier}

The standard consistency of EN140 and EN280 cyclone ashes, as well as the EN140 ash and Auvere ESPA was quite high (Table 5). The initial setting of ash pastes started between 40 and 310 minutes and took notably more time in the case of the EN140 ash and EN280 CA. The setting of EN140 ESPA did not start before 24 hours, which was probably due to the organics present in the ash (Table 3). The final setting times varied between 115 and 720 minutes. Experience has shown that the initial setting times of ashes remain within 60-120 minutes and final setting times within 120-300 minutes. The large expansion of unground DeSOx ash and EN280 BA could be decreased by grinding the materials up to $500 \mathrm{~m}^{2} / \mathrm{kg}$ (Table 5). 
Table 5. The standard consistency, setting times and Le Chatelier expansion of ashes

\begin{tabular}{|c|c|c|c|c|c|}
\hline Ash Parameter & $\begin{array}{c}\text { Standard } \\
\text { consistency, \% }\end{array}$ & $\begin{array}{l}\text { Initial setting } \\
\text { time, min }\end{array}$ & $\begin{array}{l}\text { Final setting } \\
\text { time, min }\end{array}$ & $\begin{array}{c}\text { Expansion, } \\
\mathrm{mm}\end{array}$ & $\begin{array}{l}\text { Expansion, } \\
\text { mm (ash ground) }\end{array}$ \\
\hline DeSOx & 30 & 120 & 220 & 30.0 & 10.0 \\
\hline EN140 CA & 46 & 270 & 540 & 1.0 & \\
\hline EN140 CA2-3 & 64 & 310 & 720 & 2.0 & \\
\hline EN140 ESPA & 65 & $>30 \mathrm{~h}$ & - & 1.0 & \\
\hline EN280 BA & 36 & 75 & 240 & - & 7.0 \\
\hline EN280 CA & 51 & 255 & 660 & 6.0 & \\
\hline EN280 total & 35 & 40 & 205 & 2.0 & \\
\hline Auvere total & 43 & 180 & 395 & 3.0 & \\
\hline Auvere ESPA & 64 & 45 & 115 & 0.0 & \\
\hline
\end{tabular}

\subsubsection{Hardening dynamics of ash mortars}

The DeSOx ash-containing test pieces were tested at 28 days (Fig. 6a). The binding properties of Auvere ESPA-containing hardened mortars were superior to those of all the other ash mortars tested (Table 6). Achieving the required hardening and compressive strength, as well obtaining durable stones without any cracks presented problems with other ash types (Fig. 6). The grinding of coarse bottom and total ashes as well as capsulated DeSOx ash somewhat increased their strength and decreased water demand (Table 6, Fig. 7).

Table 6. The bending strength (three replicas) and compressive strength (six replicas) of ash mortars (* the strength of test objects was not adequate for analysis)

\begin{tabular}{|c|c|c|c|c|c|c|c|}
\hline \multirow[t]{2}{*}{ Parameter } & \multirow[t]{2}{*}{ Water/ash ratio } & \multicolumn{3}{|c|}{$\begin{array}{l}\text { Bending strength, } \\
\mathrm{N} / \mathrm{mm}^{2}\end{array}$} & \multicolumn{3}{|c|}{$\begin{array}{c}\text { Compressive strength, } \\
\mathrm{N} / \mathrm{mm}^{2}\end{array}$} \\
\hline & & $7 \mathrm{~d}$ & $14 \mathrm{~d}$ & $28 \mathrm{~d}$ & $7 \mathrm{~d}$ & $14 \mathrm{~d}$ & $28 \mathrm{~d}$ \\
\hline DeSOx & 0.50 & $*$ & 0.64 & 0.70 & 0.3 & 3.8 & 5.4 \\
\hline EN140 CA & 0.61 & 0.19 & 0.35 & 0.25 & 0.6 & 1.2 & 1.0 \\
\hline EN140 CA2-3 & 0.78 & 0.28 & 0.26 & 0.05 & 1.1 & 1.2 & 0.4 \\
\hline EN140 ESPA & 0.89 & 0.17 & 0.27 & 0.15 & 0.7 & 1.4 & 1.1 \\
\hline EN280 BA & 0.80 & * & * & $*$ & $*$ & $*$ & $*$ \\
\hline EN280 CA & 0.70 & * & 0.20 & 0.25 & $*$ & 0.6 & 0,7 \\
\hline EN280 total & 0.61 & $*$ & $*$ & $*$ & $*$ & $*$ & 0.3 \\
\hline Auvere total & 0.61 & 0.32 & 0.75 & 0.79 & 1.8 & 2.5 & 2.9 \\
\hline Auvere ESPA & 0.78 & 1.34 & 1.77 & 1.68 & 5.2 & 7.6 & 7.5 \\
\hline
\end{tabular}


(a)

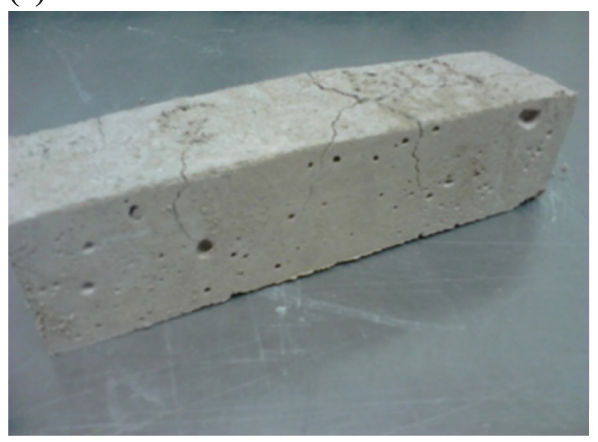

(c)

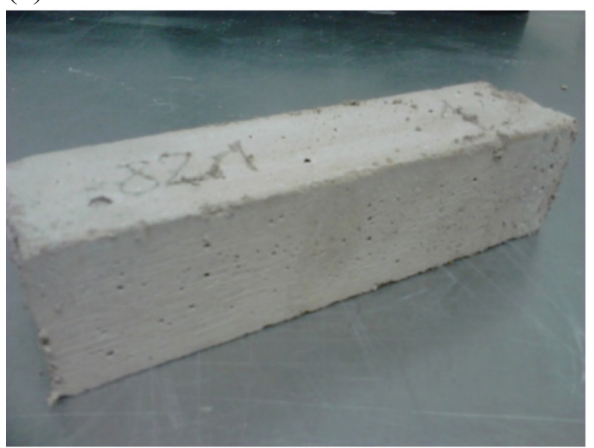

(e)

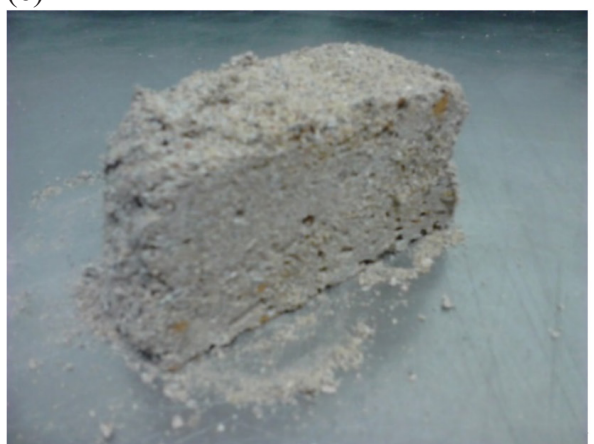

(b)

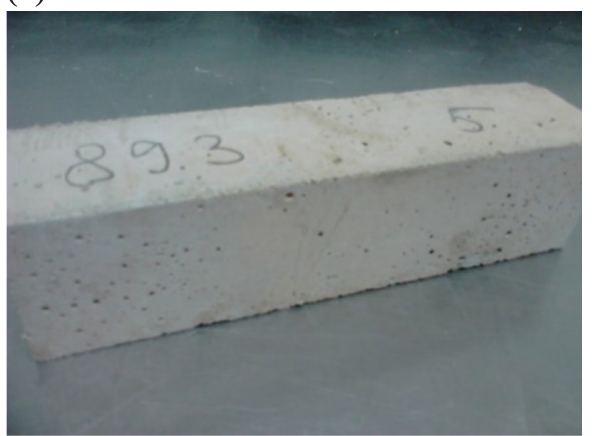

(d)

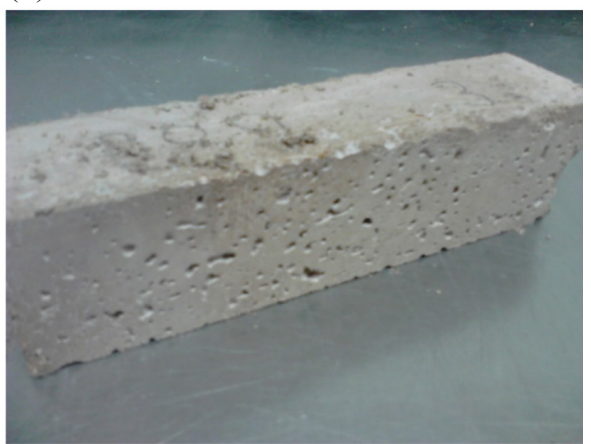

(f)

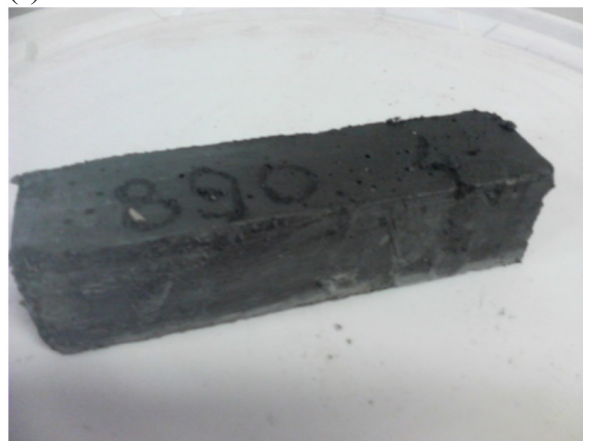

Fig. 6. Ash stones (ash:sand 1:3) of (a) DeSOx ash, (b) Auvere total, (c) EN280 CA, (d) EN280 total, (e) EN280 BA, (f) EN140 ESPA.

The types of burnt oil shale (oil shale ash) and requirements for usage are given in a national standard [63]. The modernisation of Estonian oil shale industry has resulted in the change of the composition as well as binding properties of the ashes generated. Analysis showed EN140 and EN280 ashes to be unfit for usage as binders. Auvere ESPA turned out to be the only suitable binder. Coarse Auvere and EN280 bottom and total ashes should be subjected to pre-treatment through milling before being used as binders. It would also be 


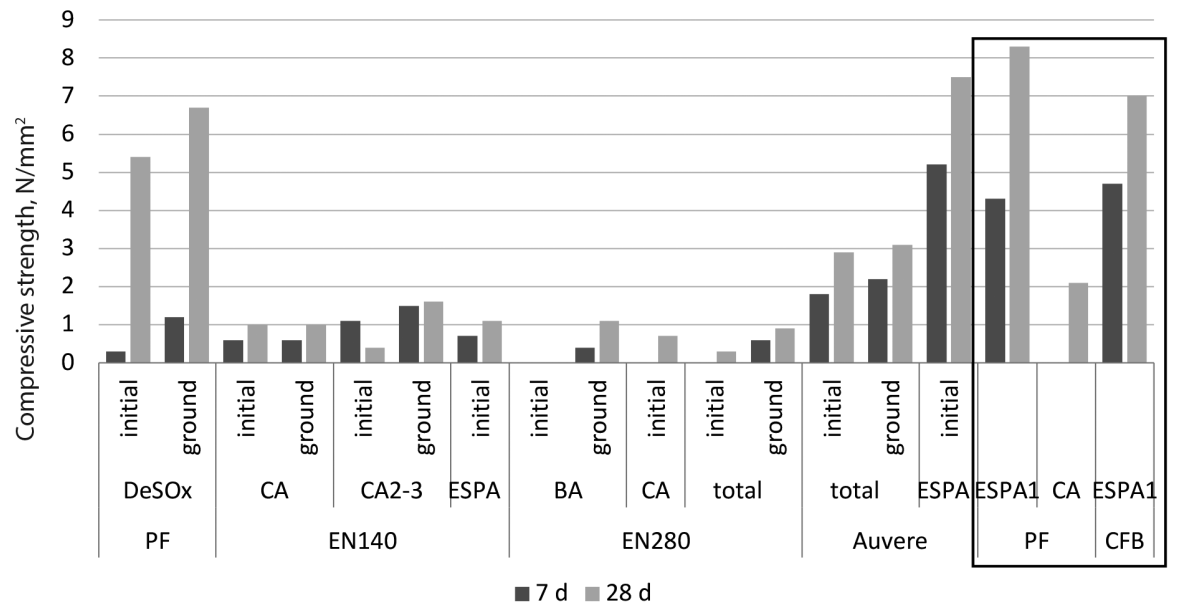

Fig. 7. The compressive strength of ash mortars (initial and ground ash) determined in the current study after seven and 28 days of hardening in comparison with that of PF ESPA1, PF CA and CFB ESPA1 ash found in a previous study [15].

worth exploring the use of the fine pozzolanic ash from Enefit 140 and Enefit 280 units as an ingredient in mixed binder materials. The recovery rate of OS ashes in conventional solutions also depends on the demand for construction materials and related logistics. Areas of large-scale use include road construction, mass stabilization, building materials production, and agriculture. From a logistical point of view, the viability of the fields depends on demand, which ensures minimum critical volumes from the aspect of transport costs. On the other hand, in addition to the low cost of OSA, the OS production residues logistics in Estonia is shaped by the geographical location of production, as well as demand, and restrictions to the choice of suitable transport modes. Therefore, the search for novel non-conventional OS ash applications should continue. The oil shale ash-based production of precipitated calcium carbonate is one option that is currently under development [64-66].

\section{Conclusions}

A new set of information on the chemical and physical composition as well as structural characteristics of solid residues (ashes) forming in updated oil shale processing technologies in Estonian oil shale industry is presented. The results obtained will form the basis for the further optimisation of deposition conditions, as well as utilisation-recycling processes of ash of changed composition and characteristics.

The new types of oil shale ash from Enefit280 and Enefit140 units contain significantly less free lime and more undecomposed carbonates when compared 
to ashes from pulverised firing and circulating fluidised bed boilers analysed previously. The Enefit 140 ash also contains organic carbon and sulphides.

The ashes studied are characterised by the basic reaction in water and leaching of salts, especially sulphates and chlorides, into the aqueous medium. In the longer term, the release of $\mathrm{Cr}$, Mo and $\mathrm{Ba}$ from fly ash may exert an adverse impact on the aquatic environment. The Enefit140 electrostatic precipitator ash discharges both monobasic and dibasic phenols at a concentration of $1.5 \mathrm{mg} / \mathrm{kg}$ and $0.3 \mathrm{mg} / \mathrm{kg}$, respectively.

The alkaline effect may pose a problem if oil shale ash is treated as a waste. Considering burnt oil shale as a by-product of energy or oil production means that it can be used as a raw material, in which case the alkalinity becomes an advantage. With the modernisation of oil shale industry the composition of ash has changed, as have its binding properties. Of the ashes tested, only Auvere electrostatic precipitator ash was found to have potential as a binder. The coarse total ashes from Auvere Power Plant and Enefit280 units, as well as capsulated DeSOx ash, would require pre-treatment through milling before being used as binders. The pozzolanic ash of higher specific surface, such as Enefit140 finer ash fractions and Enefit280 cyclone ash, should be further studied for use as an ingredient in mixed binders.

\section{Acknowledgements}

The Estonian Ministry of Education and Research (SF0140082s08, IUT33-19), the European Regional Development Fund (RITA1/01-01-07) and Eesti Energia AS are acknowledged for financial support for this study.

\section{REFERENCES}

1. Ots, A. Oil Shale Fuel Combustion. Tallinn University of Technology, Tallinn, 2006.

2. Neshumayev, D., Pihu, T., Siirde, A., Järvik, O., Konist, A. Solid heat carrier oil shale retorting technology with integrated CFB technology. Oil Shale, 2019, 36(2S), 99-113.

3. Konist, A., Pikkor, H., Neshumayev, D., Loo, L., Järvik, O., Siirde, A., Pihu, T. Co-combustion of coal and oil shale blends in circulating fluidized bed boilers. Oil Shale, 2019, 36(2), 114-127.

4. Hotta, A., Parkkonen, R., Hiltunen, M., Arro, H., Loosaar, J., Parve, T., Pihu, T., Prikk, A., Tiikma, T. Experience of Estonian oil shale combustion based on CFB technology at Narva Power Plants. Oil Shale, 2006, 22(4S), 381-397.

5. Pihu, T., Arro, H., Prikk, A., Parve, T., Loosaar, J. Combustion Experience of Estonian Oil Shale in Large Power Plants. In: International Conference on Oil Shale: "Recent Trends in Oil Shale", 7-9 November 2006, Amman, Jordan, 2006. 
6. Pihu, T., Konist, A., Neshumayev, D., Loo, L., Molodtsov, A., Valtsev, A. Fullscale tests on the co-firing of peat and oil shale in an oil shale fired circulating fluidized bed boiler. Oil Shale, 2017, 34(3), 250-262.

7. Konist, A., Valtsev, A., Loo, L., Pihu, T., Liira, M., Kirsimäe, K. Influence of oxy-fuel combustion of Ca-rich oil shale fuel on carbonate stability and ash composition. Fuel, 2015, 139, 671-677.

8. Loo, L., Maaten, B., Siirde, A., Pihu, T., Konist, A. Experimental analysis of the combustion characteristics of Estonian oil shale in air and oxy-fuel atmospheres. Fuel Process Technol, 2015, 134, 317-324.

9. Yörük, C. R., Meriste, T., Sener, S., Kuusik, R., Trikkel, A. Thermogravimetric analysis and process simulation of oxy-fuel combustion of blended fuels including oil shale, semicoke, and biomass. Int. J. Energ. Res., 2018, 42(6), 2213-2224.

10. Yörük, C. R, Trikkel, A., Kuusik, R. Prediction of flue gas composition and comparative overall process evaluation for air and oxyfuel combustion of Estonian oil shale, using Aspen Plus Process Simulation. Energy Fuels, 2016, 30(7), 5893-5900.

11. Kuusik, R., Uibu, M., Kirsimäe, K., Mõtlep, R., Meriste, T. Open-air deposition of Estonian oil shale ash: Formation, state of art, problems and prospects for the abatement of environmental impact. Oil Shale, 2012, 29(4), 376-403.

12. Pihu, T., Arro, H., Prikk, A., Rootamm, R., Konist, A., Kirsimäe, K., Liira, M., Mõtlep, R. Oil shale CFBC ash cementation properties in ash fields. Fuel, 2012, 93, 172-180.

13. Bityukova, L., Mõtlep, R., Kirsimäe, K. Composition of oil shale ashes from pulverized firing and circulating fluidized-bed boiler in Narva Thermal Power Plants, Estonia. Oil Shale, 2010, 27(4), 339-353.

14. Mõtlep, R., Sild, T., Puura, E., Kirsimäe, K. Composition, diagenetic transformation and alkalinity potential of oil shale ash sediments. J. Hazard. Mater., 2010, 184(1-3), 567-573.

15. Raado, L.-M., Kuusik, R., Hain, T., Uibu, M., Somelar, P. Oil shale ash based stone formation - hydration, hardening dynamics and phase transformations. Oil Shale, 2014, 31(1), 91-101.

16. Irha, N., Uibu, M., Jefimova, J., Raado, L.-M., Hain, T., Kuusik, R. Leaching behaviour of Estonian oil shale ash-based construction mortars. Oil Shale, 2014, 31(4), 394-411.

17. Paaver, P., Paiste, P., Liira, M., Kirsimäe, K. Alkali activation of Estonian Carich oil shale ashes: a synthesis. Oil Shale, 2019, 36(2S), 214-225.

18. Usta, M. C., Yörük, C. R., Hain, T., Paaver, P., Snellings, R., Rozov, E., Gregor, A., Kuusik, R., Trikkel, A., Uibu, M. Evaluation of new applications of oil shale ashes in building materials. Minerals, 2020, 10(9), 765.

19. Liiv, J., Teppand, T., Rikmann, E., Tenno, T. Novel ecosustainable peat and oil shale ash-based 3D-printable composite material. SM\&T, 2018, 17, e00067.

20. Paiste, P., Liira, M., Heinmaa, I., Vahur, S., Kirsimäe, K. Alkali activated construction materials: Assessing the alternative use for oil shale processing solid wastes. Constr. Build. Mater., 2016, 122, 458-464. 
21. Berber, H., Tamm, K., Leinus, M.-L., Kuusik, R., Uibu, M. Aggregate production from burnt oil shale and $\mathrm{CO}_{2}$ - an Estonian perspective. Oil Shale, 2019, 36(3), 431-447.

22. Berber, H., Tamm, K., Leinus, M.-L., Kuusik, R., Tõnsuaadu, K., Paaver, P., Uibu, M. Accelerated carbonation technology granulation of industrial waste: Effects of mixture composition on product properties. Waste Manage. Res., 2020, 38(2), 142-155.

23. Talviste, P., Kirsimäe, K. Reuse of oil shale fly ash as a hydraulic binder for strengthening soft soils. IPT Projektijuhtimine, Töö Nr 16-11-1304 (in Estonian). https://www.energia.ee/-/doc/8457332/ettevottest/pdf/uuringu_tulemused_1.pdf (accessed 23.09.2020).

24. Uibu, M., Somelar, P., Raado, L.-M., Irha, N., Hain, T., Koroljova, A., Kuusik, R. Oil shale ash based backfilling concrete - Strength development, mineral transformations and leachability. Constr. Build. Mater., 2016, 102(Part 1), 620-630.

25. Loide, V. Relieving the calcium deficiency of field soils by means of liming. Agron. Res., 2010, 8(IIS), 415-420.

26. Kaljuvee, T., Jefimova, J., Loide, V., Uibu, M., Einard, M. Influence of the postgranulation treatment on the thermal behaviour and leachability characteristics of Estonian oil shale ashes. J. Therm. Anal. Calorim., 2018, 132(1), 47-57.

27. Velts, O., Uibu, M., Kallas, J., Kuusik, R. Waste oil shale ash as a novel source of calcium for precipitated calcium carbonate: Carbonation mechanism, modeling, and product characterization. J. Hazard. Mater., 2011, 195, 139-146.

28. Uibu, M., Velts, O., Kuusik, R. Developments in $\mathrm{CO}_{2}$ mineral carbonation of oil shale ash. J. Hazard. Mater., 2010, 174(1-3), 209-214.

29. Uibu, M., Tamm, K., Velts-Jänes, O., Kallaste, P., Kuusik, R., Kallas, J. Utilization of oil shale combustion wastes for PCC production: Quantifying the kinetics of $\mathrm{Ca}(\mathrm{OH})_{2}$ and $\mathrm{CaSO}_{4} \cdot 2 \mathrm{H}_{2} \mathrm{O}$ dissolution in aqueous systems. Fuel Process. Technol., 2015, 140, 156-164.

30. Paaver, P., Paiste, P., Kirsimäe, K. Geopolymeric potential of the Estonian oil shale solid residues: Petroter solid heat carrier retorting ash. Oil Shale, 2016, 33(4), 373-392.

31. Reinik, J., Heinmaa, I., Mikkola, J.-P., Kirso, U. Hydrothermal alkaline treatment of oil shale ash for synthesis of tobermorites. Fuel, 2007, 86(5-6), 669-676.

32. Reinik, J., Heinmaa, I., Kirso, U., Kallaste, T., Ritamäki, J., Boström, D., Pongrácz, E., Huuhtanen, M., Larsson, W., Keiski, R., Kordás, K., Mikkola, J.-P. Alkaline modified oil shale fly ash: Optimal synthesis conditions and preliminary tests on $\mathrm{CO}_{2}$ adsorption. J. Hazard. Mater., 2011, 196, 180-186.

33. Reinik, J., Heinmaa, I., Mikkola, J.-P., Kirso, U. Synthesis and characterization of calcium-alumino-silicate hydrates from oil shale ash - Towards industrial applications. Fuel, 2008, 87(10-11), 1998-2003.

34. Kaasik, A., Vohla, C., Mõtlep, R., Mander, Ü., Kirsimäe, K. Hydrated calcareous oil-shale ash as potential filter media for phosphorus removal in constructed wetlands. Water Res., 2008, 42(4-5), 1315-1323. 
35. Kõiv, M., Liira, M., Mander, U., Mõtlep, R., Vohla, C., Kirsimäe, K. Phosphorus removal using Ca-rich hydrated oil shale ash as filter material - the effect of different phosphorus loadings and wastewater compositions. Water Res., 2010, 44(18), 5232-5239.

36. Kuusik, R., Uibu, M., Toom, M., Muulmann, M.-L., Kaljuvee, T., Trikkel, A. Sulphation and carbonization of oil shale CFBC ashes in heterogeneous systems. Oil Shale, 2005, 22(4S), 421-434.

37. Yörük, C. R., Uibu, M., Usta, M. C., Kaljuvee, T., Trikkel, A. $\mathrm{CO}_{2}$ mineralization by burnt oil shale and cement bypass dust: effect of operating temperature and pre-treatment. J. Therm. Anal. Calorim., 2020, 142, 991-999.

38. Reispere, H. J. Determination of free $\mathrm{CaO}$ content in oil shale ash. Trans. Tallinn Polytech. Institute, Ser A Nr 245, 1966, 73-76 (in Estonian).

39. EVS 664:1995. Solid Fuels. Sulphur Content. Determination of Total Sulphur and its Bonding Forms. 1995 (in Estonian).

40. UNI EN 12457-2: 2004. Leaching - Compliance Test for Leaching of Granular Waste Materials and Sludges. Part 2: One Stage Batch Test at a Liquid to Solid Ratio of $10 \mathrm{l} / \mathrm{kg}$ for Materials with Particle Size below $4 \mathrm{~mm}$.

41. DIN EN 16171:2016. Sludge, Treated Biowaste and Soil - Determination of Elements Using Inductively Coupled Plasma Mass Spectrometry (ICP-MS).

42. DIN EN ISO 10523:2012. Water Quality-Determination of $p H$.

43. DIN EN 27888 (C8). Water Quality - Determination of Electrical Conductivity.

44. DIN EN ISO 17294-2 (E29). Water Quality-Application of Inductively Coupled Plasma Mass Spectrometry (ICP-MS) - Part 2: Determination of Selected Elements Including Uranium Isotopes.

45. DIN EN ISO 10304-1 (D20). Determination of Dissolved Anions by Liquid Chromatography of Ions - Part 1: Determination of Bromide, Chloride, Fluoride, Nitrate, Nitrite, Phosphate and Sulfate.

46. EVS-EN 196-6:2018. Methods of Testing Cement-Part 6: Determination of Fineness.

47. EVS-EN 933-1:2012. Tests for Geometrical Properties of Aggregates. Part 1: Determination of Particle Size Distribution. Sieving Method.

48. EVS-EN 196-5:2011. Methods of Testing Cement-Part 5: Pozzolanicity Test for Pozzolanic Cement.

49. EVS-EN 196-3:2016. Methods of Testing Cement - Part 3: Determination of Setting Times and Soundness.

50. EVS-EN 196-1:2016. Methods of Testing Cement - Part 1: Determination of Strength.

51. Kuusik, R., Uibu, M., Kirsimäe, K. Characterization of oil shale ashes formed at industrial-scale CFBC boilers. Oil Shale, 2005, 22(4S), 407-419.

52. Saether, O. M., Banks, D., Kirso, U., Bityukova, L., Sorlie, J.-E. The chemistry and mineralogy of waste from retorting and combustion of oil shale. In: Energy, Waste and the Environment: a Geochemical Perspective (Gieré, R., Stille, P., Eds.). Geol. Soc., London. Special Publications, 236, 2004, 263.

53. Laja, M., Urb, G., Irha, N., Reinik, J., Kirso, U. Leaching behavior of ash 
fractions from oil shale combustion by fluidized bed and pulverized firing process. Oil Shale, 2005, 22(3), 453-465.

54. Reinik, J., Irha, N., Steinnes, E., Piirisalu, E., Aruoja, V., Schultz, E., Leppänen, M. Characterization of water extracts of oil shale retorting residues from gaseous and solid heat carrier processes. Fuel Process. Technol., 2015, 131, 443-451.

55. Tamm, K., Kallaste, P., Uibu, M., Kallas, J., Velts-Jänes, O., Kuusik, R. Leaching thermodynamics and kinetics of oil shale waste key components. Oil Shale, 2016, 33(1), 80-99.

56. Potential Hazardousness of Estonian Oil Shale Ashes. Report, 1.07.2019, Tallinn University of Technology and University of Tartu (in Estonian). https://www. envir.ee/sites/default/files/tuhaohtlikkus_aruanne.pdf (accessed 8.11.2019).

57. Eesti Energia. Oil Shale Ash, 2018. https://www.energia.ee/en/tuhk (accessed 21.03.2019).

58. Directive 2013/39/EU of the European Parliament and of the Council of 12 August 2013 Amending Directives 2000/60/EC and 2008/105/EC as Regards Priority Substances in the Field of Water Policy. Official Journal of the European Union, L 226, 24.8.2013.

59. The Environmental Quality Limit Values for the Surface Water and Their Methods of Application, and the Environmental Quality Limit Values for Water Biota. Riigi Teataja I, 18.12.2013, 5 (in Estonian).

60. Irha, N., Reinik, J., Steinnes, E., Urb, G., Kirso, U., Jefimova, J. Leachability of trace elements from the aged and fresh spent shale deposit - A field study. Oil Shale, 2013, 30(3), 456-467.

61. EVS 636:2002. Burnt Oil-Shale for Production Portland Burnt Shale Cement, Portland Composite Cement and Masonry Cement. Withdrawn on 03.12.2015.

62. Kikas, W. Composition and binder properties of Estonian kukersite oil shale ash. ZKG Int., 1997, 50(2), 112-126.

63. EVS 927: 2018. Burnt Shale for Building Materials: Specification, Performance and Conformity.

64. Ragn-Sells filed patent applications for the enhancement of oil shale ash, ERR News 26.06.2020. https://news.err.ee/1106432/ragn-sells-filed-patentapplications-for-the-enhancement-of-oil-shale-ash

65. Kuusik, R., Uus, M., Uibu, M., Stroganov, G., Parts, O., Trikkel, A., Pepoyan, V., Terentiev, A., Kalnapenk, E. Method for Neutralization of Alkaline Waste Water with Carbon Dioxide Consisting in Flue Gas. Patent EE200600041, priority date 22.12.2006.

66. Kuusik, R., Uibu, M., Uus, M., Velts-Jänes, O., Trikkel, A., Veinjärv, R. Method for Eliminating $\mathrm{CO}_{2}$ from Flue Gases by Calcium Compounds Containing Industrial Wastes. Patent P200900040, priority date 8.06.2009. 